\title{
The Influence of Tropical Cyclones to the Plant Productivity Indices along the Coast of Tanzania
}

\author{
Kombo Hamad Kai1,2, Yohanna Wilson Shaghude ${ }^{1,2}$, Agnes Lawrence Kijazi ${ }^{3,4}$, Christian B. Uiso ${ }^{3,4}$ \\ ${ }^{1}$ Tanzania Meteorological Authority (TMA), Zanzibar, Tanzania \\ ${ }^{2}$ Institute of Marine Sciences (IMS) of University of Dar es Salam (UDSM), Mizingani Road, Zanzibar, Tanzania \\ ${ }^{3}$ TMA, Ubungo Plaza, Dar es Salaam, Tanzania \\ ${ }^{4}$ Department of Physics, University of Dar es Salaam (UDSM), Tanzania \\ Email: kombo.kai@meteo.go.tz, kombokai68@gmail.com, agnes.kijazi@meteo.go.tz, \\ shaghude@ims.udsm.ac.tz,bsuiso2010@gmail.com,cbuiso@uccmail.co.tz
}

How to cite this paper: Kai, K.H., Shaghude, Y.W., Kijazi, A.L. and Uiso, C.B. (2021) The Influence of Tropical Cyclones to the Plant Productivity Indices along the Coast of Tanzania. Atmospheric and Climate Sciences, 11, 589-613.

https://doi.org/10.4236/acs.2021.113036

Received: March 4, 2021

Accepted: July 12, 2021

Published: July 15, 2021

Copyright $\odot 2021$ by author(s) and Scientific Research Publishing Inc. This work is licensed under the Creative Commons Attribution International License (CC BY 4.0).

http://creativecommons.org/licenses/by/4.0/

(c) (i) Open Access

\begin{abstract}
The study investigated the influence of Tropical cyclone (TCs) to the plant productivity indices along the coast of Tanzania using both field observations and change detection methods. These indices are normally designed to maximize the sensitivity of the vegetation characteristics and are very crucial in monitoring droughts intensity, yield and biomass amongst others. The study used three types of satellite imageries including the 16 days Moderate Resolution Imaging Spectroradiometer (MODIS) of $250 \times 250 \mathrm{~m}$ resolution; 8 days Landsat 7 enhanced thematic mapper (ETM) with resolution of $30 \times 30 \mathrm{~m}$ composites, and 5 Landsat 8 (LC8) images, to determine the patterns and the variability of the Normalized Difference Vegetation Index (NDVI) and Enhanced Vegetation Index (EVI) and TCs impacts on vegetation. Moreover, we used Tropical Rainfall Measuring Mission (TRMM) data and the daily to monthly rainfall data from Tanzanian Meteorological Authority (TMA). The change detection between the pre and post storm (TCs) conditions was used to analyse inter annual variability of EVI over Chwaka, Rufiji and PuguKazimzumbwi. The changes in NDVI and EVI and monthly rainfall at the coastal stations were calculated, plotted and analyzed. The results revealed that, highest EVI values over coastal Tanzania were observed during March and April, and minimum (low) values in November. The results for EVI changes based on pre and post storm conditions revealed that most observed stations and most TCs led to significant EVI changes which ranged from -0.05 to 0.19 , and -0.3 to 0.22 , for MODIS and L7 ETM data, respectively. As for the spatial changes in NDVI results revealed that, TCs (Besija and Fobane)
\end{abstract}


were associated with positive NDVI changes i.e. (enhancement) of $>0.51$ and $>0.31$, and NDVI reduction (i.e. negative changes) of $<0.02$ and $<-0.19$ for Chwaka and Rufiji, respectively. Besides the results revealed that, TCs episodes have induced a land cover changes from i.e. water covered areas changed to be vegetation covered especially over the shorelines and inter tidal areas. Indeed, these results were consistent with the analysis of rainfall patterns which indicated that low rainfall occurred in low NDVI areas and vice versa.

\section{Keywords}

Tropical Cyclones (TCs) Impacts, Normalized Vegetation Index (NDVI), Enhanced Vegetation Index (EVI), Rainfall, MODIS), Tanzania

\section{Introduction}

Tropical cyclones and storms, like other large natural disturbances, play a vital role in regulating ecosystem structure and affecting diverse plant and animal populations and communities [1] [2]. In most cases plant physiognomy and its spectral characteristics exhibit abrupt changes in response to atmospheric disturbances such as cyclones, tornadoes, tsunamis, drought, deforestation among others [3] [4] [5]. Nowadays there is an increasingly application of remotely sensed data in detecting the spatial and spectral changes in land cover classes [6] [7] [8]. The change detection of pre and post event satellite images plays a vital role in assessing vegetation responses influenced by abrupt changes of weather caused by natural events such as heavy rainfall, tsunamis and TC events [5] [6] and [9]. The change in biomass and other related spectral responses varies based on type and intensity of disturbance, land cover type, and other environmental factors. There are various change detection techniques such as classification, principle component analysis of the classified images, images differencing, rationing among others [5], but no single method is best to all problems in all environment, each method is good to a specific problem and in a given environmental settings.

Normalized Difference Vegetation Index (NDVI) is a dimensionless index that can describe the difference between visible and near-infrared reflectance of vegetation cover and can be used to estimate the density of green on an area of land [10]. NDVI which varies between -1 and 1 , is one of the most common indices widely applied for monitoring vegetation dynamic at regional and global scales [11] [12]. Enhanced vegetation Index (EVI) is similar to NDVI and has a huge attention on monitoring the vegetation quality and quantity (i.e. vegetation greenness). In most cases EVI corrects for some atmospheric conditions and canopy background noise and is more sensitive in areas with dense vegetation.

Efforts to extract numerical observations related to vegetation dynamics [13] [14] using per-pixel time series of the NDVI or EVI are hindered by noise aris- 
ing from varying atmospheric conditions and sun-sensor-surface viewing geometries [15]. Cloud, ozone, dust, and other aerosols generally decrease near infrared reflectance, which in turn leads to spurious drops in Vegetation Index (VI) [6] [7]. On global scale the study by [16] [17] [18] [19] and [20] among others have been tried to understand and quantify the impacts of severe weather (e.g. flooding and TCs) to the vegetation productivity, regeneration, mangrove canopies among others.

Many studies concerning the influence of rainfall variability to NDVI changes [21] [22] as well as the influence of atmospherics tele-connections such as ENSO to the vegetation variability [23] have been moderately conducted in East African (EA). Since TCs are not commonly made land landfall to the EA coast (Tanzania in particular) and are rarely tracking close to Tanzanian coast (except for few observed cases e.g. Lindi (occurred in 1952) and Lily (occurred in 1882) [24] [25], the study of the influence of TCs to the changes in plant biomass (NDVI) seems to be very limited or not yet done. Despite of not making landfall to Tanzanian coast, but TCs associated impacts (e.g. strong winds, flooding and extreme tides [26] on land cover changes can't be ignored. These land cover impacts either declines/enhances the productivity/photosynthetic characteristics of affected land cover areas, hence affecting the plant NDVI (biomass) [27], which is generated from Near-IR, Red and Blue bands of each scene, with a range bounded at $[-1.0-1.0]$.

Vegetation indices such as EVI and NDVI [28] play an important role in monitoring vegetation variations in global, regional and even in country and local scales. These variations are aimed to provide consistent spatial and temporal information of vegetation in these time scales. Moreover, vegetation indices e.g. NDVI has proven to be a proxy for the status of the above ground biomass at the landscape level due to the high correlation with green-leaf density, net primary production and $\mathrm{CO}_{2}$ fluxes [29] [30], hence DVI can be used to monitor draughts and yields.

Since TCs affects on plant biomass changes over East Africa (EA) and Tanzanian in particular, thus the understanding of the influence of TCs to vegetation productivity indices is a virgin research area which needs a lot of inputs to critically understand and evaluate the extent to which TCs affects the biomass over coastal Tanzania. Among others things this study was aimed at understanding and quantifying the extent to which TCs disturbances affects the plant productivity indices (NDVI and EVI) over the Chwaka-Jaozani, Rufiji Delta and PuguKazimzumbwi coastal reserve areas of Tanzania using observation and optical remote sensing techniques such as change detection.

This paper is organized into 4 sections as follows. Section 2 describes the study areas, data sets, data processing techniques and the analytical methods used. Section 3 discusses the main results that include inter annual variability of EVI, the influence some cited of TCs to EVI over Chwaka, Rufiji and Pug Kazimzumbwi reserve forests, the spatial changes in NDVI over Chwaka and Rufiji 
delta among others.. Section 4 closes the study by discussions and conclusions

\section{Materials and Methods}

\subsection{The Study Areas}

The study area for analyzing the influence of TCs to the NDVI and EVI was the reserved coastal forests of Tanzania, which includes Rufiji delta, Chwaka-Jozani and Pugu-Kazimzumbwi (Figure 1). The basis for selecting these areas was 1) North-south comparison of the TCs impacts on vegetation productivity induces 2) Logistic reasons.

Rufiji basin is composed of two main parts i.e., the upper and lower Rufiji with the total area of about $177,000 \mathrm{~km}^{2}$. The lower Rufiji has a total area of about $19,215 \mathrm{~km}^{2}$ and is composed of the lower seasonal inundated flood plain which is estimated to have an area of about $14,200 \mathrm{~km}^{2}$ [31], known as Rufiji Delta. The Delta is located at the east coast of southern Tanzania, with a deltaic plain of approximately $65 \mathrm{~km}$ wide and extends $123 \mathrm{~km}$ inland [32] [33]. The delta has two main parts, southern and northern and is mainly dominated by mangrove substrata which are formed approximately $2.5 \mathrm{~m}$ above mean sea level [34]. This study uses the lower Rufiji plain and specifically the northern delta

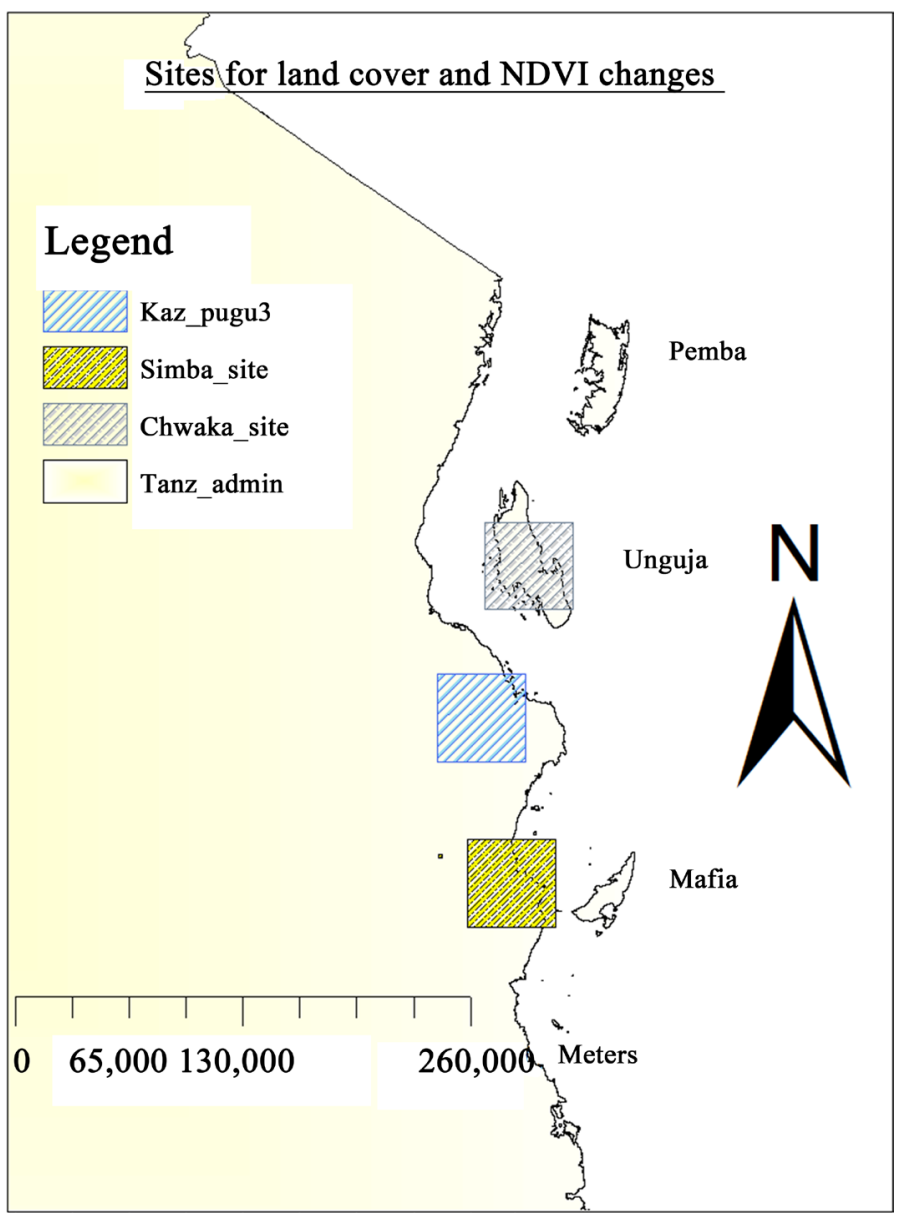

Figure 1. The study sites for the TCs EVI and NDVI analysis. 
for its NDVI and EVI analysis. Climatologically, the delta lies in the unimodal rainfall regime with peak rainfall during December to March (DJFM). During December to February (DJF), South Western Indian Ocean (SWIO) is marked by its peak and frequent season of TCs/TSs [35]. This TCs/TSs induces the sea-level rise, storm surges, strong winds and strong waves as well as moderate to heavy rainfall which in turn results into wilting of plants and damaging of vegetation and crops due to long time water lodging [18]. On the other hand flooding has resulted into inversion of foreign species into the delta hence endanger the life of mangroves in the delta [17]. Ultimately the influence of TCs induced disturbances to the Rufiji delta fallout in declining of NDVI and EVI. Socioeconomically Rufiji Delta is engulfed with many livelihood activities such as rice and maize farming, fishing and livestock keeping, among others. On the other hand since the delta is the leading mangrove forest (about $500 \mathrm{~km}^{2}$ coverage) over EA [36], the socio-economical activities such as local and external commercial trades of the woodland resources (poles, charcoal and building materials) are taking place [37]. These activities environmentally degrade the Rufiji delta, and hence results into declined NDVI and EVI.

\section{Chwaka-Jozani Forest Reserve}

Chwaka-Jozani forest reserve is situated approximately $6.04^{\circ} \mathrm{S}-6.2^{\circ} \mathrm{S}$ and 39.39 ${ }^{\circ} \mathrm{E}-39.53^{\circ} \mathrm{E}$ at the east coast of Zanzibar Island, and is located about $22 \mathrm{~km}$ from the Zanzibar town, with an area of approximately $50 \mathrm{~km}^{2}$ [38]. To the south the Chwaka bay is surrounded by mangrove strips of Charawe and Ukongoroni [39] and Jozani forest reserve. The western bay strip is mainly a sand beach with little inlet tributaries going inland. Chwaka Bay is composed of three distinct types of vegetation (i.e. terrestrial coastal zone, Mangrove zone and sandy/beach front zone). The mangrove zones of Chwaka are estimated to cover about 300 ha [40] and are found in sandy-muddy and rock dominated areas. The terrestrial coastal zone forest comprise of tall indigenous trees, plantation of exotic (foreign) species, shrub layers and number of epiphytic plants [41] [42].

Climatically, Chwaka bay has temperature ranges of $23^{\circ} \mathrm{C}-28^{\circ} \mathrm{C}$ during South East Monsoon (SE) and $28^{\circ} \mathrm{C}-35^{\circ} \mathrm{C}$ during the Northeast monsoon (NE) with highest occurs during January to February (JF). Chwaka-Jozani area lies in the bimodal rainfall regime of October to December (OND) and March to May (MAM) rainfalls. During December the area is influenced by light to moderate NE monsoon winds which are associated with light rains; whereas during JF the area is dry. During December to March (DJFM), Chwaka-Jozani is affected by the, SWIO peak TCs season ([43] [44] [45] [46] [47]) which leads most of Chwaka-Jozani area to get moderate to heavy rainfall associated with these TCs. The main climatic drivers of vegetation changes over Chwaka-Jozani are episodes of heavy rainfall, strong winds and strong waves especially during the TCs and during the SE monsoon. These TCs based disturbances are the main driver which results in enhancing/declining of NDVI and EVI. The main socio economic activities of the people living at Chwaka-Jozani are terrestrial (e.g. farming), local fishing (using deferent gears), sea weed farming and mangrove cutting (for build- 
ing materials and timber harvesting [42], whereas few of them are engaged into the coastal and mangrove conservation programs.

\section{Pugu-Kazimzumbwi Forest Reserve}

This is one of the three forest reserves (i.e. Kazimzumbwi, Pugu and Ruvu South Forest) situated at Kisarawe District. Pugu-Kazimzumbwi is approximately 20 $\mathrm{km}$ from Dar es Salaam City and spans from $38.68^{\circ} \mathrm{E}$ to $38.69^{\circ} \mathrm{E}$ and $6.86^{\circ} \mathrm{S}$ to $7.19^{\circ} \mathrm{S}$ within Kisarawe District ([48]). The Pugu-Kazimzumbwi has an area of about 7077 hectares. Pugu Forest Reserve has an area of 2179 ha while Kazimzumbwi Forest Reserve land 4887 hectares. Climatically the forest reserve is characterized by an average temperature of about $28^{\circ} \mathrm{C}$ with an annual rainfall ranging between 800 to $1100 \mathrm{~mm}$ [48]. The Pugu-Kazimzumbwi lie in bimodal rainfall regime with peak rains on March to June and October and December. The main socio-economic activities of the Kisarawe residents include local farming and extracting woodland resources (charcoal, timber and poles) for commercial and house hold usage.

\subsection{Sources of Data}

The data used for this study consisted of remote sensing satellite data acquired from three sensors of land sat images, namely Land sat Thematic Mapper (TM), Land sat Enhanced Thematic Mapper plus (ETM+) and landsat 8 (LC8). The Land sat TM consists of seven bands with wavelengths ranging from $0.52-12.5$ $\mu \mathrm{m}$ for bands $1-7$ and $0.52-0.60$ for panchromatic bands, respectively. The Land sat images have spatial resolutions of $30 \times 30 \mathrm{~m}$ for multispectral bands and $15 \mathrm{~m}$ for panchromatic. The spectral wavelengths of these bands lends to many regional to national scale investigations, including analyses of water quality, ecosystem health, wildlife habitat, land cover assessment, land use planning, urban studies, urban sprawl, and other land management issues ([49]). Land sat Enhanced Thematic Mapper plus (ETM+) has the same characteristics as Land sat TM, but with more applications such as navigation of poorly charted areas (especially in the Arctic and Antarctic), mapping of faults and fracture zones. Moreover, L7ETM+ is used as the basis for mapping the tectonic activity, as well as finding unmapped volcanic fields. In this study long term (2000-2014) $30 \times 30$ $\mathrm{m} 8$ days TM and ETM+ composite data was down loaded from (https://earthengine.google.org/\#detail/LANDSAT\%2FLT5 L1T 8DAY EVI) and

(https://earthengine.google.org/\#detail/LANDSAT\%2FLE7 L1T 8DAY EVI). These data sets were used for analysis of NDVI and EVI, respectively.

Land sat 8 (LC8): The main objective for land sat (LC8) mission was to provide timely, high quality visible and infrared images of all landmass and near-coastal areas on the earth. Like the TM and ETM, LC8 has a resolution of $30 \times$ $30 \mathrm{~m}$ for multispectral bands and $15 \mathrm{~m}$ for panchromatic. The main deference between the LC8 and TM and ETM+ is that LC8 have additional thermal 2 band (11.50 - 12.51), Coastal aerosol (0.43 - 0.45), and Cirrus (1.36 - 1.38) bands. In this 
study 5 LC8 images for Chwaka-Jozani, Rufiji delta and Pugu-Kazimzumbwi were used to analyze the spatial NDVI changes associated with pre and post TC events.

Moderate Resolution Imaging Spectro radiometer (MODIS) is a key instrument aboard NASSA's Terra (EOS AM) and Aqua (EOS PM) satellites. The MODIS sensors provide the data in three resolutions such as $250 \mathrm{~m}, 500 \mathrm{~m}$ and $1 \mathrm{~km}$, respectively. The MODIS Terra data sets contains the sixteen days $250 \times 250 \mathrm{~m}$ composites which has an advantage of eliminating most cloud cover found in daily basis. In this study long term (2000-2014) $250 \times 250 \mathrm{~m} 16$ days MODIS composite from MCD43A4 MODIS

(https://earthengine.google.org/\#detail/MODIS \%2FMCD43A4_EVI) was used. Moreover, daily and monthly rainfall observation over Tanzanian coastal stations was acquired from TMA. This dataset was mostly that from coastal stations as well as daily observed data during the presence of the cyclones Fobane, Besija among others. Other type of data used, was the Tropical Rainfall Measuring Mission (TRMM) satellite data of horizontal resolution of $0.25^{\circ} \times 0.25^{\circ}$ [50] [51] was acquired from TRMM website (http://pmm.nasa.gov/TRMM). The main reason of using TRMM was to visualize areas having high/low rainfall to influence the vegetation changes in line with checking results from the pre and post storm images used to quantify the changes in NDVI and EVI.

\subsection{Data Processing}

During extracting the long term composite data sets for TM, ETM+ and MODIS, the rectangular polygons for each study area was defined and constructed. The grid points for the constructed polygons were $39.07^{\circ} \mathrm{E}$ to $39.43^{\circ} \mathrm{E}$ and $7.47^{\circ} \mathrm{S}$ to $8.47^{\circ} \mathrm{S}$ for Rufiji, $39.28^{\circ} \mathrm{E}$ to $39.52^{\circ} \mathrm{E}$ and $6.13^{\circ} \mathrm{S}$ to $6.28^{\circ} \mathrm{S}$ for Chwaka and $38.9^{\circ} \mathrm{E}$ to $39.2^{\circ} \mathrm{E}$ and $6.85^{\circ} \mathrm{S}$ to $7.1^{\circ} \mathrm{S}$ for Pugu Kazimzumbwi, respectively. Also as for long term composite data of MODIS and Landsat TM and ETM+, mean pre and post storm EVI data was extracted for at least one month period before and after cyclones Kalunde (2002), Gafilo (2004), Bondo (2006), Felleng (2013) and Fobane (2014) was analyzed. The one month period was taken based on the fact that changes in plant phonology due to disturbance take some time to be detected [20].

Landsat 8 (LC8) data was used for calculating the spatial changes in NDVI based on pre and post TCs conditions. The TC events used in pre and post cyclone NDVI calculations includes Fobane (February, 2014) and Besija (December, 2013 to January, 2014). Over Chwaka-Jozani forest reserve the images used for pre storm (Fobane and Besija) NDVI analysis were LC8 images of $14^{\text {th }}$ September, 2013 and $5^{\text {th }}$ February, 2014. These images had percentage cloud cover of $13.4 \%$ and $9.9 \%$, respectively. As for the post storm (Fobane and Besija) NDVI analysis only one LC8 image of $25^{\text {th }}$ March, 2014 was used. This image had a percentage cloud cover of $9.6 \%$. The time coverage from pre to post image conditions for TC Fobane was about 52 - 53 days while that of Besija was about 88 
days.

Over Rufiji, the pre LC8 image which was used for the spatial NDVI analysis was on $14^{\text {th }}$ September, 2013, with $13.4 \%$ cloud cover. This image was taken about 3 month before Besija and four months before Fobane. The next clear image for post storm condition was obtained on $13^{\text {th }}$ June, 2014 (i.e. four months after Fobane and six months after Besija). One could notice that the period taken for the pre and post image condition was long; this was attributed by the fact that it was very difficult to get cloud free image over Rufiji during December to March. The period from December to May is very active in TCs and seasonal rainfall over Rufiji. During the 2013/2014 TCs season, three more TCs e.g. Amara (December, 2013), Bruce (December, 2013) and severe TS Guinto (February, 2014) had brought rainfall impacts to Rufiji. Thus, the two images used for Rufiji area not only cover the seasonal TCs impacts, but also quantify the NDVI impacts due to 2013/2014 seasonal severe weather impacts of both rainfall and TCs. It was decided to use EVI composite data because it was designed to reduce atmospheric effects due to aerosols and gaseous absorption, moreover is less prone to saturation with dense leaf canopies than NDVI [52].

The long term monthly rainfall observation data from TMA was calculated into seasonal totals and plotted into time series so as to observe the extent to which the high EVI periods are matched with high TCs and rainfall period. The daily rainfall observation data from coastal stations was used to show how coastal stations were affected by rainfall during TCs occurrence.

TRMM data was used to extract the rainfall during the specific TC's life, and the total gridded rainfall based on each cited TC was calculated using Grid Analysis and Display System (GrADS) software and plotted in spatial maps. Apart from cloud cover and seasonality, other criterion used for selection of the images used for NDVI changes was based on the level of impacts which the specific TC either directly or indirectly caused to human well-being. The best recorded example was Fobane which was having maximum sustainable winds of $31.3 \mathrm{~ms}^{-1}$ with gusts to $38 \mathrm{~ms}^{-1}$ and having a good column of moisture from surface to $700 \mathrm{mb}$. The strong winds and moisture sucking effect of this cyclone resulted into devastating effects that extended as far as Zanzibar and Pemba Islands.

\section{Methods for Calculating the NDVI and EVI}

This study used the band 4 and 5 of the LC 8 images under Geographic Resources Analysis Support System (GRASS) GIS software version 7.0 beta conditions, to calculate at surface reflectance under Dark Object Subtraction (DOS) algorithm, using the simplified at-surface values of the DOS methods. In this method, atmospheric correction and reflectance calibration removed the path radiance (i.e. the stray light from the atmosphere and the spectral effect of solar illumination). The equations used to calculate surface radiance and surface reflectance are well explained by the studies of [9] [53] and [45]). After completion of the image-processing steps, the NDVI of the processed images was then cal- 
culated using reference [54] expression given by:

$$
\mathrm{NDVI}=\frac{\mathrm{NIR}-\mathrm{RED}}{\mathrm{NIR}+\mathrm{RED}}
$$

where NIR refers to near infra red, which is similar to TM/ETM band 4, and Red is similar to TM/ETM band 3 whereas for LC8 it is band 4 and 5 respectively. The right-hand side of Equation (1) i.e. (NIR - RED)/(NIR + RED) enables the NDVI to minimize the noise caused by changing sun angles, topography and other atmospheric conditions. (e.g., clouds, shadows among others). Thus, this is why NDVI is widely used as an operational global-based vegetation index ([7]).

The change between the post and pre TC events (i.e. post-pre) were determined using the approaches discussed by [6] and [5] where the difference in NDVI values were classified into three categories, namely "Negative change", "No changes" and "Positive changes". The thresholds for negative, no change and positive changes were obtained from the difference image (post-pre cyclone NDVI changes) frequency distribution statistics of $\mu \pm \sigma$, where $\mu$ and $\sigma$ are the mean and standard deviation of the deference NDVI image. In this case, the three categories were defined by:-

1) If the NDVI changes in the difference image was less than $\mu-\sigma$, then the change was considered to be "Negative change" (i.e. all areas in the difference image which have NDVI values less than $\mu-\sigma$ were considered to have declined NDVI).

2) All areas in the difference image having NDVI values in the range of " $\mu-\sigma$ to $\mu+\sigma$ " were considered to "No change".

3) All areas in the difference image having NDVI values greater than $\mu+\sigma$ were considered to have "Positive change" (i.e. enhanced NDVI).

Normally histogram distributions with significant changes in NDVI will tend to be tailed while histogram distributions with no significant change have a tendency of pixels being clustered around the mean ([5]). Interpretation of the results was appraised by the ground-truthing results (i.e. the NDVI and EVI changes were compared with the changes observed during the field work). The uncertainties i.e. error bars showing whether these differences were statistically significant was also determined. The data (i.e. difference between the pre and post NDVI and EVI) was also subjected to other statistical analyses such as t-test. Finally, this data was compared with the rainfall acquired from TRMM and local meteorological coastal stations.

\section{Results}

\subsection{Spatial NDVI Estimations from LC8 Images}

The results of the NDVI changes over Chwaka-Jozani reserve forest, presented in Figures 2(a)-(c) revealed that, both TC events had either declined or enhanced the NDVI. The difference between pre and post images for both cyclones shows significant changes in NDVI. Also the recovery image after the cyclone 


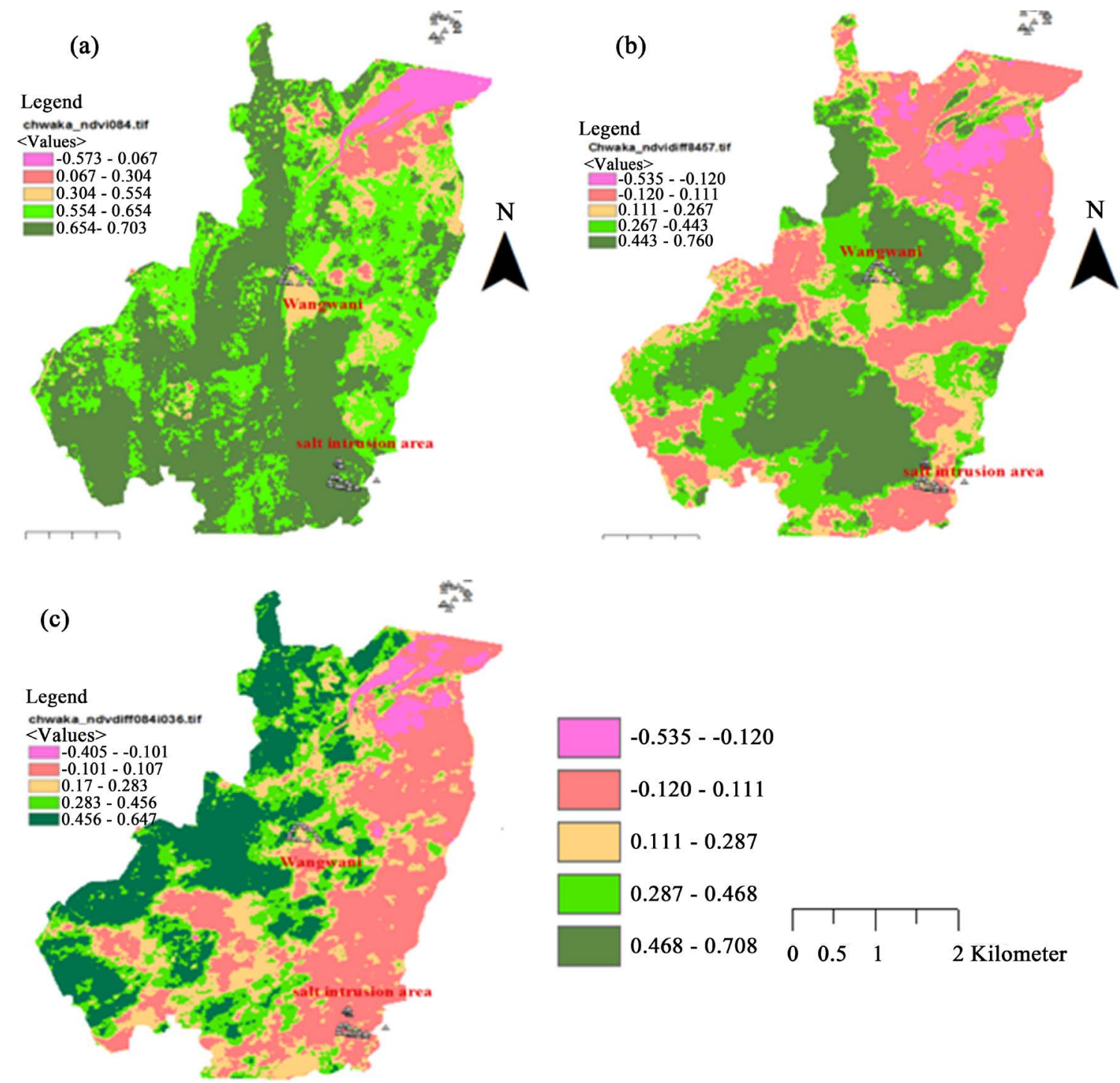

Figure 2. NDVI changes over Chwaka for pre and post TCs of Besija and Fobane over Chwaka (a) Post Besija and Fobane (b) difference between pre and post Besija (c) difference for pre and post Fobane.

Figure 2(a) shows an improvement of NDVI. The results in Figure 2(b) \& Figure 2(c) (i.e. the differences between pre and posts) show that, there was a great change in NDVI over Jozani forest especially in areas which are prone to percolation or direct salt water intrusion e.g. Wangwani. Over these areas, the saltwater intrusion have resulted a reduction in NDVI ranging from -0.120 to 0.267 and -0.101 to 0.263 for Besija and Fobane, respectively. In both cases the NDVI was more declined over the eastern part compared to western part of the forest reserve. Moreover, the results revealed that TC Fobane had shown an effect on under store forest layers than Besija indicating that there was more salt water intrusion through percolation during Fobane than during Besija.

The results of the statistical analysis of $\mu$ and $\sigma$ of the difference images (postpre) revealed that Fobane and Besija had $\mu$ and $\sigma$ of 0.25 and 0.22 as well as 0.27 and 0.24 , respectively. This implies that under both TCs conditions, areas having 
NDVI change of $<0.03$ and $<0.04$ were registered, and were associated with negative changes (i.e. reduction in NDVI), and areas having NDVI changes of 0.03 to 0.47 and 0.04 to 0.51 were associated with no changes, whereas areas having changes of $>0.47$ and $>0.51$ were associated with positive changes i.e. enhanced NDVI. In general over Chwaka bay TC Besija had resulted a reduction in NDVI ranged from $-0.101-0.170$ and an NDVI enhancement of $0.46-0.69$, while TC Fobane had resulted in NDVI reduction by a range of $-0.12-0.11$ and enhanced by $0.47-0.70$, respectively.

The results of the NDVI changes over Rufiji presented in Figures 3(a)-(c) revealed the strong seasonal impacts of TCs and rainfall. In general the results presented in Figure 3(b) showed the improvement of NDVI after the TC season with a great change in NDVI over shorelines. Moreover, Figure 3(b) showed that over the mangrove areas NDVI have increased from the range of $0.6-0.8$ to the range of $0.6-0.9$, while over the river channels, NDVI had greatly increased due to increased deposition of sediments. The results of the difference between pre and post conditions (net change) presented in Figure 3(c) show that NDVI has increased from 0.3 - 0.7 over the shorelines, while an overall change over the delta was $-0.042-0.135$ especially over the mangrove areas. Moreover, the results show that the 2013/2014 TCs season had resulted into great deposition of eroded sediments over the shorelines, the phenomenon which result into great change of NDVI from the range of -0.52 to -0.109 (water covered) to the range of $0.135-0.711$ (vegetation covered). On the other hand, the results of the difference image statistics ( $\mu$ and $\sigma$ ) show that the difference image had a $\mu$ of 0.06
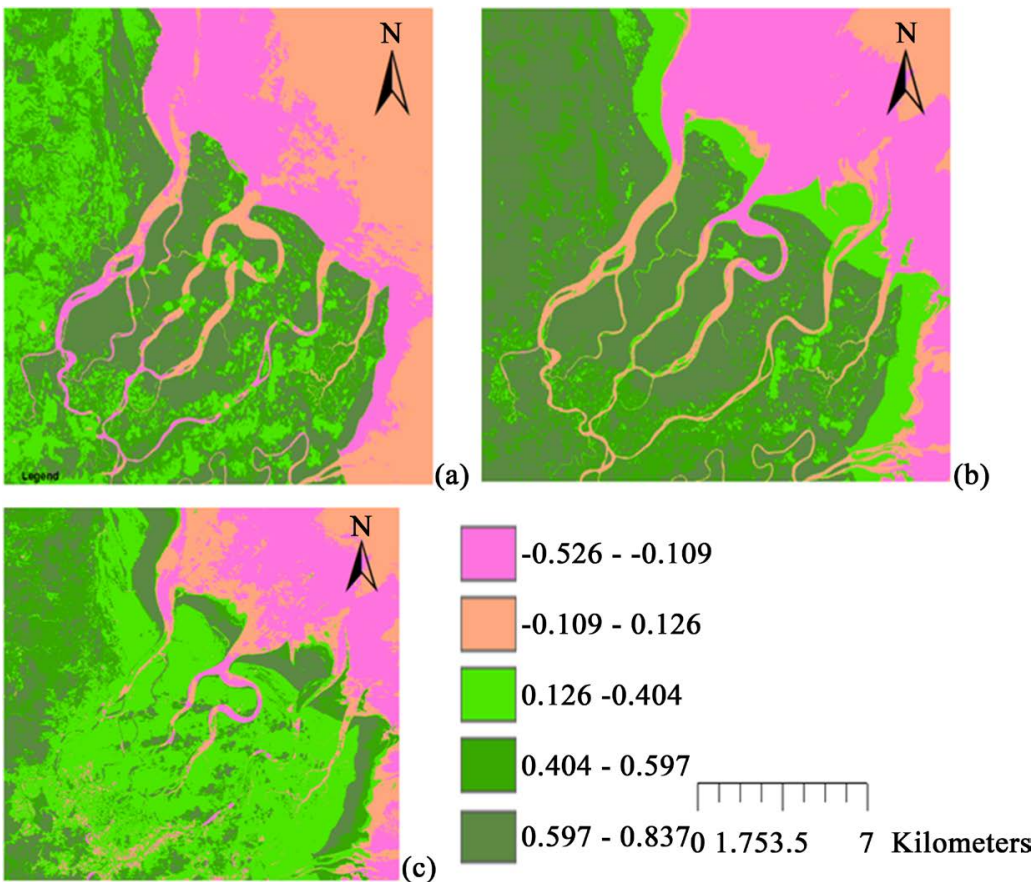

Figure 3. NDVI changes over Rufiji for pre and post TCs of Besija and Fobane over Rufiji (a) pre Besija and Fobane (b) post Besija and Fobane (c) difference between pre and post Bessija and Fobane. 
and $\sigma$ of 0.25 . The results of identifying areas with significant changes in NDVI using $\mu$ and $\sigma$ show that areas having NDVI changes of $<-0.19$ was referred to have negative change, areas having NDVI changes of -0.19 to 0.31 were referred to have no change, while areas having NDVI changes of $>0.31$ were referred to have positive changes. This analysis indicates that the shoreline areas were having significant changes in NDVI. Generally, the results had shown that December to May period had resulted into great change in deposition of sediments over

Rufiji River and its (tributaries) as well as its shorelines; the phenomenon which resulted into increased regeneration of new mangroves hence increased the productivity.

\subsection{EVI Estimations from Composite Data}

The results of the monthly and seasonal variation of EVI over each study area presented in Figure 4 revealed that, the year 2002 was the greenest over all study cites with March EVI being the highest compared to other periods. Moreover, all curves for 2002 except that of January over Chwaka showed an increasing trend of EVI as shown in Figures 4(a)-(c). On the other hand, the results of the monthly mean EVI variation presented in Figure 4(d) showed that April, May and June had the peak values of EVI whereas August, September and November had the least EVI values over each study cite. Furthermore, the results revealed that in each study cite the EVI values were increasing from December through June and decreases from July through November, where the highest EVI (0.5 0.65) was observed on April and May for Chwaka and Pugu, while that of Rufiji was observed during May and June.

Comparatively, Pugu-Kazimzumbwi had the highest EVI values while, Rufiji have the lowest ones. Generally the monthly mean EVI values in Figure 4(d) revealed the sinusoidal nature of variation, reflecting the influence of seasonal rainfall. Moreover, Figure 4(d) showed that the EVI changes over Chwaka and Pugu-Kazimzumbwi had two peaks of March to May (MAM) and September through December (SOND) reflecting the bimodal rainfall regime characteristics, while Rufiji EVI had only single peak of April through June showing the behavior of unimodal rainfall regime characteristics.

\subsection{The Influence of TCs on Enhanced Vegetation Index (EVI).}

The results of the EVI changes based on pre and post storms conditions presented in Figure 5 reveal that there are significant changes for mean EVI before and after the TCs events. These results are not only consistent with error bars for each storm and for each station, but also are consistent with the results of the paired t-test presented in Table 3. The EVI changes results presented in Figure 5 are consistent with the results presented in Figure 4 as well as the results presented in Figure 6 and Figure 7 where the mean EVI time series over Chwaka, Rufiji, and Pugu-Kazimzumbwi had their peak values during the period of TCs occurrences as shown by the vertical lines in Figure 6. Moreover, results in Fig- 
ure 6 revealed that over all stations the highest peak was that due to Kalunde (2002) followed by Felleng and Fobane. Across stations results revealed that $\mathrm{Pu}-$ gu-Kazimzumbwi had the highest EVI values compared to Chwaka and Rufiji. On the other hand, the results in Figure 6 has shown that, Chwaka which had a monthly mean peak EVI of about 0.9 , which is associated with TCs Izilda $\left(26^{\text {th }}\right.$ $29^{\text {th }}$ March, 2009) and TC Jade ( $2^{\text {nd }}-11^{\text {th }}$ April, 2009). The occurrence of TC
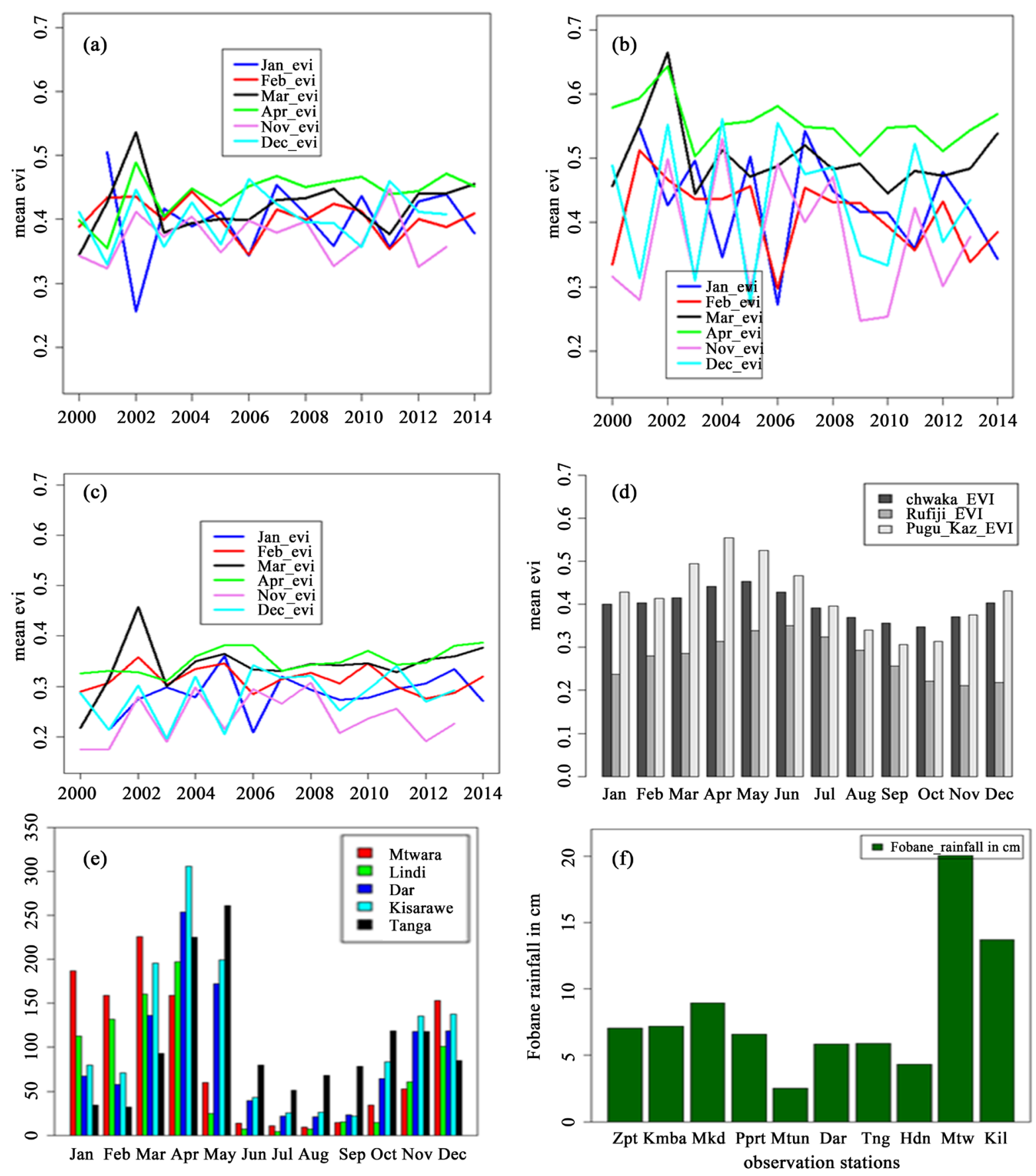

Figure 4. Inter annual variability of EVI for six peak months of TCs over SWIO basin reserve forests of (a) ChwakaJozani (b) Pugu-Kazimzumbwi (c) Rufiji delta (d) EVI Monthly averages for all three forest sites (e) Monthly rainfall over some stations and (f) The station observation rainfall due to TC Fobane. 

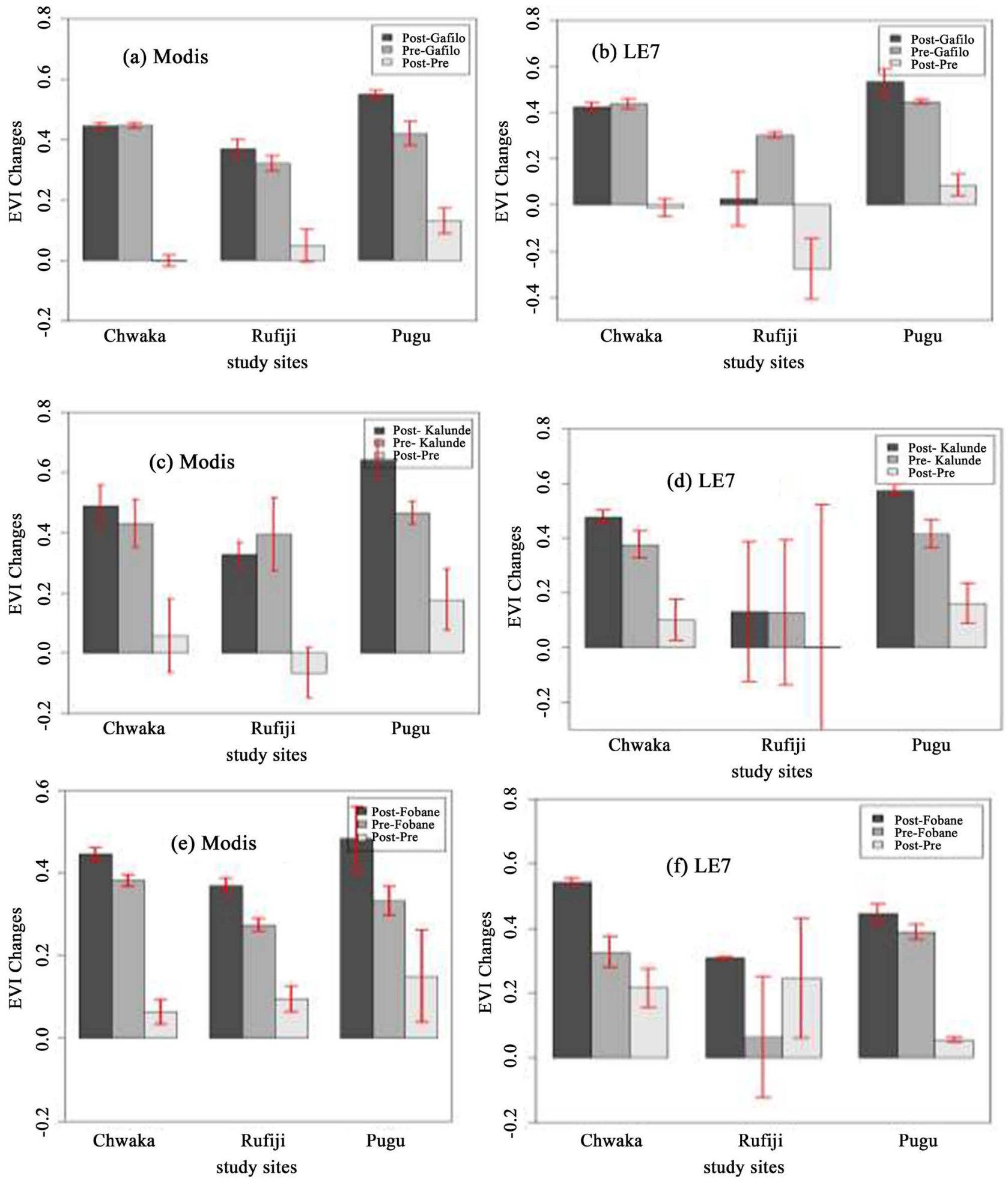

Figure 5. Pre and post EVI changes for MODIS and Landsat 7 (L7 ETM+) data sets where (a) \& (b) presents Gafilo (2004); (c) \& (d) Kalunde (2002); (e) \& (f) Fobane (2014). The error bars shows the standard deviations.

Izilda and Jade dried the weather over most parts of Tanzania except over the northern coast Figure 7(e). These TCs were influenced by the upper to mid level northwesterly flow and hence resulted in excessive rainfall over the northern coast. 


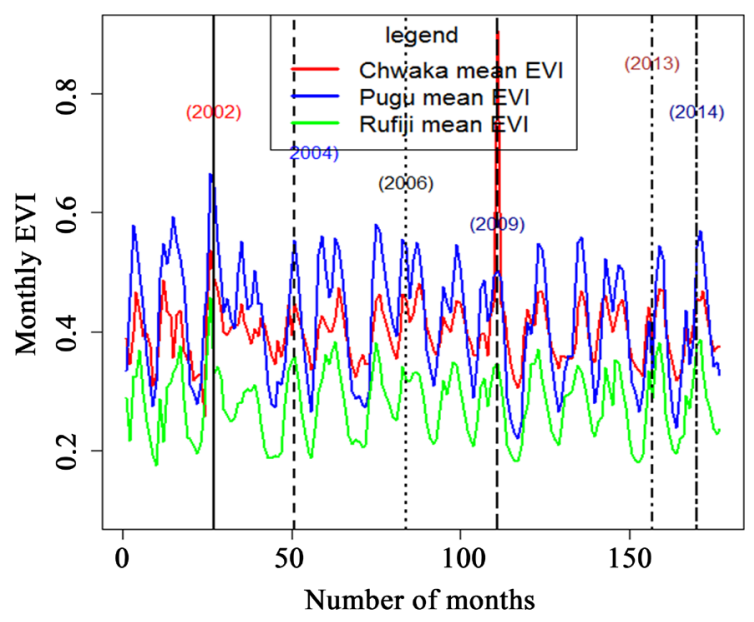

Figure 6. Monthly mean EVI (from MODIS) time series over Chwaka, Pugu-Kazimzumbwi and Rufiji. Note that vertical lines show the dates where tropical cyclones Kalunde (2002), Gafilo (2004), Bondo (2006), Izilda (2009), Felleng (2013) and Fobane (2014) occurred.

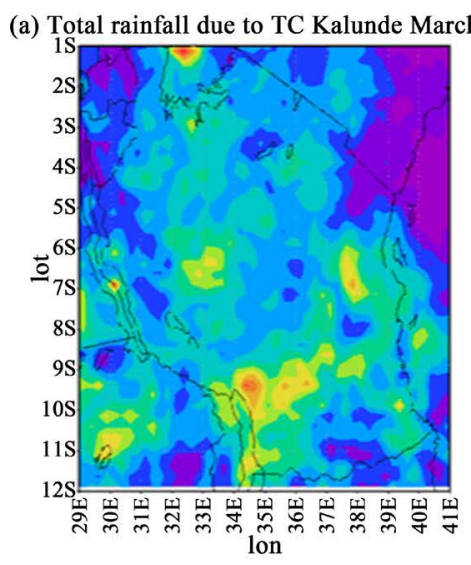

(d) Total rainfall due to TC Felleng Jan-Feb 2013

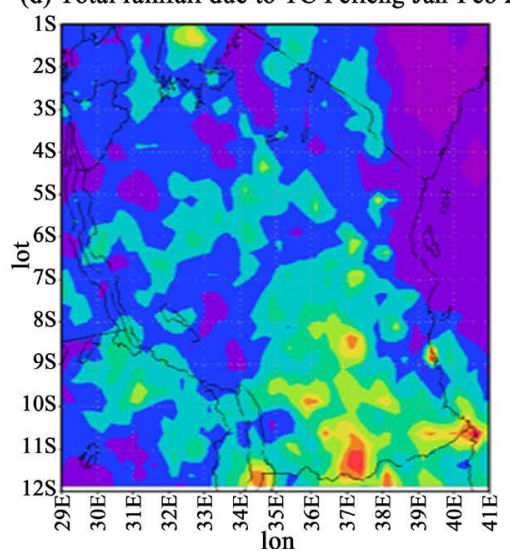

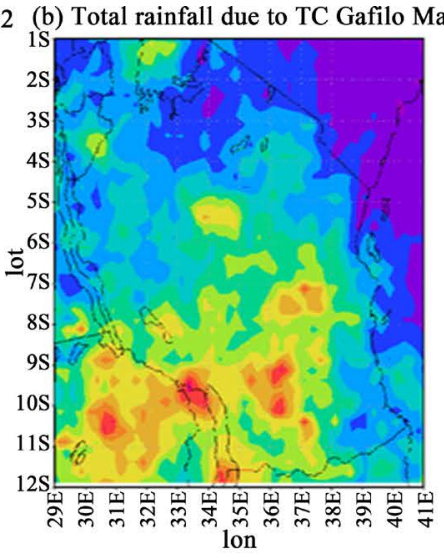

(c) Total rainfall due to TC Bondo December 2006
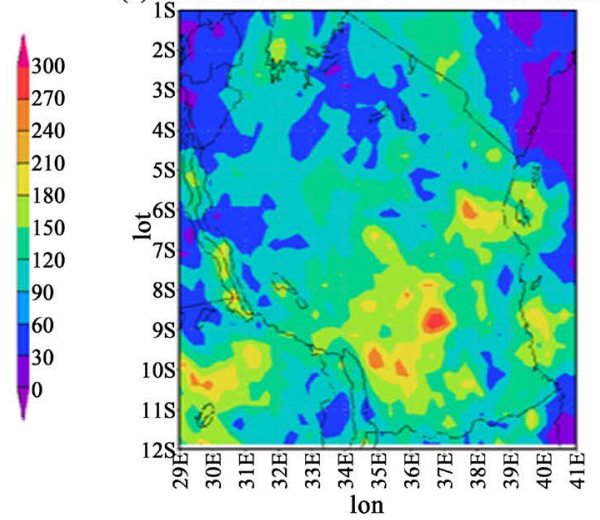

(e) 27th March 2009 TRMM rainfall due to TC Izilda

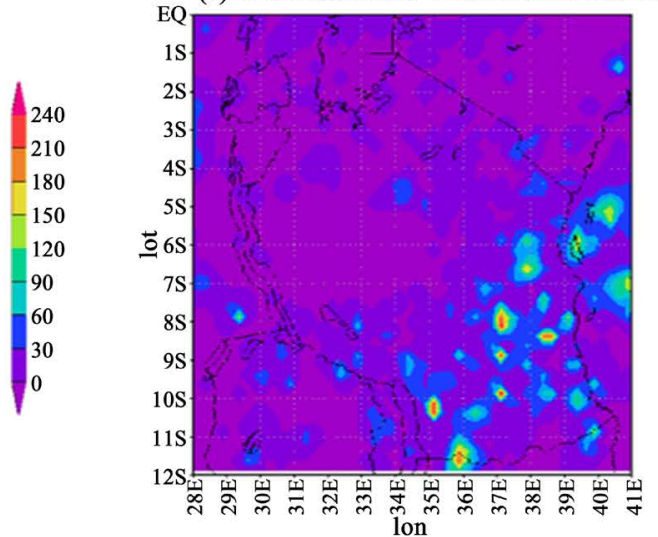

Figure 7. Total TRMM rainfall due to TCs over Tanzania where (a) is for Kalunde (b) is for Gafilo (c) is for Bondo and (d) is for Felleng and (e) Izilda (for $27^{\text {th }}$ March, 2009)

The results of EVI changes based on storm by storm descriptions presented in Table 1 and Figure 5 showed that, TC Kalunde was the strongest intense TC over Southwestern Indian Ocean (SWIO), based on MODIS EVI data; Kalunde 
has resulted into increased positive mean EVI of 0.05 and 0.18 over Chwaka and Pugu-Kazimzumbwi, and a negative change of -0.05 over Rufiji Figure 5 (c). Using the L7 ETM data Kalunde had resulted in a change of about 0.1 at Chwaka and 0.19 at Pugu and negligible change at Rufiji. Similar results were shown by TCs Gafilo and Fobane as shown in Table 1 and Figure 5. Though March 2002 was the greenest period of the 2000 decade (Figures 4(a)-(c)) but TC Kalunde have resulted a negative changes in EVI values over Rufiji and positive changes at Chwaka and Pugu Kazimzumbwi. This variation of EVI direction during Kalunde can be explained by the heavy rainfall associated by TC Kalunde (Table 2 and Figure $7(\mathrm{a})$ ).

Tropical cyclone Gafilo was the ever recorded strongest TC in SWIO basin and the most devastating in areas like Mozambique and other western coastal areas of southern Indian Ocean. Over Tanzania Gafilo had influenced heavy rainfall over southern to southwestern, central areas and even Lake Victoria and moderate rainfall over northern coast and northeastern highlands of the country as shown by Table 2 and Figure $7(\mathrm{~b})$. The influence of this TC to land cover changes can be seen using EVI changes shown by Figures 4(a)-(d) and Figure 5(a) and supported by Table 1 . Inter annual variability of mean EVI during 2004 have values ranging from 0.35 to 0.5 for Chwaka, Rufiji and Pugu. The EVI changes due to TCs Gafilo could be associated with heavy rainfall during Gafilo (Figure 7(b)); where very little total rainfall (60 - $90 \mathrm{~mm}$ ) was registered over Chwaka, (90 - $180 \mathrm{~mm}$ ) over Pugu, and (150 - $210 \mathrm{~mm}$ ) over Rufiji Table 2. The

Table 1. Comparison of EVI changes based on pre and post TCs for using the MODIS and L7ETM+ satellite composites.

\begin{tabular}{ccccccc}
\hline \multirow{2}{*}{ TC name } & \multicolumn{2}{c}{ Chwaka } & \multicolumn{2}{c}{ Rufiji } & \multicolumn{2}{c}{ Pugu-Kazimzumbwi } \\
\cline { 2 - 7 } & MODIS & L7ETM+ & MODIS & L7ETM+ & MODIS & L7ETM+ \\
\hline Kalunde & 0.05 & 0.1 & -0.05 & Very small & 0.18 & 0.19 \\
Gafilo & Very small & Very small & 0.05 & -0.3 & 0.15 & 0.1 \\
Fobane & 0.08 & 0.21 & 0.09 & 0.22 & 0.19 & 0.05 \\
\hline
\end{tabular}

Table 2. Rainfall distribution pattern at Chwaka, Pugu-Kazimzubwi and Rufiji during Kalunde, Gafilo, Bondo, Felleng and Fobane TC events.

\begin{tabular}{ccccc}
\hline \multirow{2}{*}{ TC Event } & \multicolumn{3}{c}{ Estimated total Rainfall (mm) } & $\begin{array}{c}\text { Remarks } \\
\text { Rainfall days }\end{array}$ \\
\cline { 2 - 4 } & Chwaka & Pugu-Kazimzumbwi & Rufiji & 17 days \\
\hline Kalunde $^{*}$ & $0-50$ & $50-100$ & $50-100$ & 18 days \\
Gafilo $\left(^{*}\right)$ & $0-50$ & $100-200$ & $50-100$ & 9 days \\
Bondo $\left.{ }^{*}\right)$ & $150-250$ & $100-200$ & $100-150$ & 9 days \\
Felleng $\left(^{*}\right)$ & $0-50$ & $0-50$ & $50-100$ & 6 days \\
Fobane & 55 & 53 & 130 & \\
\hline
\end{tabular}

Note that, ${ }^{*}$ and ${ }^{*}$ indicate that the information was extracted from Figure 7 , while ${ }^{*}$ indicate the in-situ observation extracted from Figure 4(e). 
little gain in EVI over Pugu as compared to Rufiji can be explained by river water flooding (water logging) as well as salt water intrusion during this severe ever recorded TC in SWIO.

The results of EVI changes due to TCs Fobane presented in Figure 5(e) \& Figure 5(f) and Table 1 revealed that both data had resulted into positive changes in EVI with higher values of up to 0.2 shown by L7 ETM+ over Chwaka and Rufiji (Table 1), whereas at Pugu the MODIS data had higher changes as compared to L7 ETM+ data. The EVI changes due to TC Fobane could be explained by strong rainfall during this $\mathrm{TC}$ which covered the entire coast and some interior. The results of EVI changes due to TC Bondo (Figure 5(e)) and MODIS data have resulted into positive changes in EVI for all sites. These changes can be explained by the rainfall due to Bondo (Figure 7(c)) and Table 2. Unlike Bondo, Felleng has influenced dry conditions (reduction in rainfall) over the entire northern coastal areas (Figure $7(\mathrm{~d})$ ). This dryness have influenced the negative changes in mean EVI conditions for the pre and post EVI condition over Chwaka and Rufiji with a positive changes over Pugu.

The results of the paired t-test correlation computed at $(\mathrm{p} \leq 0.05)$ under the hypothesis that, there were no significant differences in mean EVI values during the pre and post storm events, is presented in Table 3. The results in Table 3 show that, the bolded cells were significant; hence the null hypothesis was accepted. This implies that at the given station the TCs influence to vegetation indices was not significant. On the other hand, the unbolded numbers in Table 3 show that the paired $t$ test was not significant, hence the null hypothesis was rejected, implying that TCs disturbances to photosynthetic process were significant at that station. Further results revealed that there exists both negative and positive relationship between TCs and EVI changes. This indicates that TCs and EVI had inverse relationship between the pre and post storm conditions meaning that, TCs can either reduce/enhance the plant productive conditions (i.e.

Table 3. Paired t-tests for the mean EVI for pre and post storms conditions over Chwaka, Rufiji and Pugu-Kazimzumbwi.

\begin{tabular}{cccccccc}
\hline \multirow{2}{*}{ Storm } & \multicolumn{2}{c}{ Chwaka } & \multicolumn{2}{c}{ Rufiji } & \multicolumn{2}{c}{ Pugu-Kazimzumbwi } \\
\cline { 2 - 8 } & $\mathbf{r}$ & p-value & $\mathbf{r}$ & p-value & r & P-value \\
\hline Kalunde (March, 2002) & -0.32 & 0.25 & 0.97 & 0.151 & -0.91 & 0.047 \\
Gafilo (Mar, 2004) & -0.72 & 0.414 & -0.86 & 0.073 & -0.032 & 0.001 \\
Bondo (Dec,2006) & -0.83 & 0.11 & 0.79 & 0.014 & -0.923 & 0.19 \\
Felleng (Jan-Feb 2013) & -0.37 & 0.015 & -0.83 & 0.092 & & \\
Fobane (Feb 2014) & -0.71 & 0.004 & -0.60 & 0.001 & -0.96 & 0.02 \\
& Paired t-test for LE7 EVI changes & & \\
Kalunde(2002) & -1 & 0.1 & -1 & 0.5 & -1 & & 0.1 \\
Gafilo (2004) & -1 & 0.4 & -1 & 0.1 & -1 & & 0.1 \\
Fobane(2014) & -1 & 0.2 & -1 & 0.2 & -1 & & 0.01 \\
\hline
\end{tabular}


increase/decrease in EVI conditions), for instance, the EVI changes due to TCs Kalunde and Fellleng had significant and insignificant relationship over some study cites. Results of paired t-test using MODIS data indicate that some stations were having significant EVI differences during pre and post TCs disturbances but for LE7 TM+ most stations had significant EVI changes during pre and post disturbances (Table 3).

\section{Discussion and Conclusions}

\subsection{Discussion}

The Tanzania coastal areas are prone to most natural hazards associated to both seasonal rainfall and TCs. December to March (DJFM) is the peak and frequent season of TCs over SWIO basin with mean TSs and TCs of 2.7 and 2.2 for the defined SWIO region and seasonal rates of 10.6 TSs and 4.8 TCs for the entire SWIO basin [55]. Based on their positions track and strengths these TCs have great impacts to coastal dynamics including the land cover changes (erosion, flooding, and droughts among others) which either directly or indirectly affects the plant productivity indices of the coastal forests. In this study we have analyzed the influence of TCs and TSs to plant productivity using observation, time series data (MODIS and LT ETM+) as well as pre and post LC8 images for specific TCs of Besija and Fobane over Chwaka and Rufiji. The monthly time series of EVI showed the greenest condition on March 2002 with higher values of up to 0.75 EVI values for all stations. This higher EVI values could be attributed by high rainfall during the high and frequent TCs period of DJFM (Figure 4(e)), but Rufiji declined EVI due to Kalunde can be explained by the influence of saltwater and fresh water flooding which resulted extensive water logging. The area averaged monthly mean EVI time series showed that during March to April the coastal areas had higher EVI values with lower values occurred during November, whereas Rufiji had the lowest. Comparatively, over these three stations Rufiji had the lowest EVI values over all months used to extract the EVI time series. This could be due to the fact that during EVI extraction over Rufiji Delta the water body pixels have not been masked out. Moreover, this could also be explained by the impacts of salt splashes from the sea waves as well as evaporated salty moisture from water logged over the mangrove deserts. When these evaporated high concentration salty particles are contaminated to the plant leaves they slow the photosynthetic process [56] and result in drying of the tree from top canopies.

As for the monthly mean EVI (Figure 4(d)), Chwaka-Jozani and Pugu Kazimzumbwi EVI portrayed the behaviors of bimodal rainfall regime with peaks on March to June and December to January, whereas Rufiji (Figure 4(d)) portrayed the characteristics of unimodal rainfall regime with peak EVI on April to August. Most of the station gave significant EVI changes ranging from 0.05 0.45 (Gafilo), -0.15 - 0.25 (Kalunde), 0.1 - 0.25 (Fobane) based on (MODDIS), and $-0.4-0.15$ (Gafilo), $0.0-0.25$ (Kalunde) and $0.05-0.5$ (Fobane) based on 
(L7 ETM). Moreover, enhanced or declined EVI conditions due to cited TCs were either due to enhanced/decline rainfall as well supported by the rainfall variability (Figure 4(e) and Figure 4(f)) and total rainfall calculations and mapping for each TCs (Figure 7) where areas having declined EVI values were consistent with the areas having declines rainfall for that specific TC. The best example was that of Felleng which had declined EVI values over Rufiji and Chwaka and higher values over Pugu-Kazimzumbwi (figure not shown), this was supported by the rainfall distribution due TC Felleng (Figure 7(d)) which showed the declined rainfall over Rufiji towards northern coast (Dar es Salaam, Zanzibar and Tanga) and moderate rainfall over Pugu-Kazimzumbwi areas. Moreover, Fobane have induced higher EVI changes over all study sites (Figure 5(e) \& Figure $5(\mathrm{f})$ ), this is well supported by (Figure $4(\mathrm{f})$ ) where most coastal station were having moderate to high rainfall during the Fobane life.

The analysis of the influence of TCs using LC8 based on change detection technique showed that TCs have either enhance or reduced the NDVI over the study areas. Over Chwaka TCs have resulted a decline of NDVI of $<0.03$ and $<0.02$ and an enhancement of $>0.51$ and $>0.47$ for Besija and Fobane, respectively. This decline and enhancement of NDVI over Chwaka was showing the east west declining due to the nature of the forest where eastern part was composed of shrubs and bushes. Moreover, the declination could be due to saltwater percolation or indirect entry as well as salt splashes, whereas the enhancement could be due to rainfall associated with these storms which was consistent with station observed rainfall due Fobane (Figure 4(f)). Furthermore, during December to late March (the peak dry season) the areas are more affected by dryness condition hence decline the NDVI. Also TCs strong winds/waves may result into salt water splashes to be contaminated to plant leaves resulting into affecting tips of the plants hence decline in NDVI. In general the main course of changes in NDVI over Chwaka could be either by direct salt water intrusion through percolation, waves and winds or due to dryness coursed by dry weather conditions.

Over Rufiji the difference (post-pre) had shown an improvement of NDVI by $>0.31$ and a decline by $<-0.19$. This decline could be explained by more flooding, increased level of fresh water and sea water logging as supported by ([57] [58] [59]). Furthermore, the decline in NDVI could be explained by uprooting of mangroves due to strong waves high speed rushing water and the effect of salt water splashes on less salt resistive plants. Besides the results indicated that, over Rufiji delta the 2013/2014 TCs and heavy rainfall season had resulted into great deposition of eroded sediments over shorelines (Figures 3(a)(c)), the phenomenon which resulted into regeneration and mushrooming of mangroves and other sea water plant species; hence improved the NDVI from the range of water covered $<-0.11$ to the range of vegetation covered of $>0.14$. This higher changes in NDVI has mostly occurred over the shorelines (intertidal areas), which were mapped with highest changes in NDVI (Figures 3(a)-(c)). Besides, great deposition of sediments due to river flow and ocean dynamics 
(tidal currents) could be another reason for this deposition. Also, the decline in NDVI was due to increased biotic stress to plant productivity, because salinity results to nutritional imbalances [57], moreover, excess salinity results in restriction of photosynthetic processes due to partial stomata closure, and waste of energy in the processes of osmotic adaptation and ion exclusion [60].

In general, the study has shown that, the influence of TCs on vegetation productivity leads in reduction of EVI/NDVI due to excessive flooding, which may result in water logging, strong winds and waves which in turn results in uprooting of trees and loss of plant tops due to deposition of highly concentration salt form trapped salt water. Moreover, the saltwater intrusion over land covers with low resistance to salinity may also result in decline in NDVI. Enhancement of NDVI/EVI can be explained by the moderate to heavy rainfall and sedimentation, which result into regeneration of plants.

\subsection{Conclusions}

Based on the presented results and discussion the study concluded that:

1) TCs/TSs induced rainfall along the coast of Tanzania have multipliable impacts on vegetation productivity indices (NDVI/EVI); The nature of NDVI/EVI change (whether positive or negative) due to TSs/TCs is generally site specific, dependent of a vegetation type, the nature of TC/TS event and meteorological and the influence of hydrodynamic/oceanographic factors;

2) The 2013/2014 TCs season had resulted into significant sediment/deposition and regeneration of mangrove species, the phenomenon which improved the NDVI from the range of -0.52 to -0.11 to the range of 0.14 to 0.71 ;

3) Apart of portraying the unimodal and bimodal rainfall regime, the monthly EVI time series marked the March 2002 EVI condition to be the greenest period of the 2000-2014 decade, with higher values of up to 0.75 over all investigated stations, whereas March to April was marked with higher EVI values and lower values during November.

4) TCs influence on vegetation productivity is virgin research areas in Tanzania which needs a lot of inputs especially over the coastal strip and its nearby hinterland areas, thus more research work is needed for operational forecasting of seasonal yields along the coastal Tanzania.

\section{Acknowledgements}

The corresponding author sincerely acknowledges Benjamin Alexander, for his assistance in downloading and extracting the MODDIS and L7 ETM composites of EVI, NDVI. I also acknowledge the CCIAM programme for a six months scholarship to stay in Norway, where I got a chance to meet with Benjamin and others to discuss this work and how to go for it.

\section{Conflicts of Interest}

The authors declare no conflicts of interest regarding the publication of this paper. 


\section{References}

[1] Loope, L., Duever, M., Herndon, A., Snyder, J. and Jansen, D. (1994) Hurricane Impacts on Uplands and Freshwater Swamp Forest. BioScience, 44, 238-246. https://doi.org/10.2307/1312228

[2] William, K.M. and Paula, F.H. (1997) Detection of Vegetation Changes Associated with Extensive Flooding in a Forested Ecosystem. Photogrammetric Engineering and Remote Sensing, 63, 1363-1374.

[3] Peters, A.J., Reed, B.C., Eve, M.D. and Havstad, K.M. (1993) Satellite Assessment of Drought Impact on Native Plant Communities of Southeastern New Mexico, U.S.A. Journal of Arid Environments, 24, 305-319. https://doi.org/10.1006/jare.1993.1027

[4] Chavez, P.S. and MacKinnon, D.J. (1994) Automatic Detection of Vegetation Changes in the Southwestern U.S. Using Remotely Sensed Images. Photogrammetric Engineering \& Remote Sensing, 60, 571-583.

[5] Mansor, S.B., Al-doski, J. and Shafri, H. (2013) NDVI Differencing and Post-Classification to Detect Vegetation Changes in Halabja City, Iraq. IOSR Journal of Applied Geology and Geophysics, 1, 1-10. https://www.iosrjournals.org

[6] Jupiter, S.D., Potts, D.G., Phinn, S.R. and Duke, N. (2007) Natural and Anthropogenic Changes to Mangrove Distributions in the Pioneer River Estuary. Wetlands Ecology and Management, 15, 51-62. https://doi.org/10.1007/s11273-006-9011-9

[7] Matsushita, B., Yang, W., Chen, J., Onda, Y. and Qiu, G. (2007) Sensitivity of the Enhanced Vegetation Index (EVI) and Normalized Difference Vegetation Index (NDVI) to Topographic Effects: A Case Study in High-Density Cypress Forest. Sensors, 7, 2636-2651 https://doi.org/10.3390/s7112636

[8] Thaxton, J.M., Dewalt, S.J. and William, J.P. (2007) Spatial Patterns of Regeneration after Hurricane Andrew in Two South Florida Fringe Mangrove Forests. Biological Sciences, 70, 148-156.

[9] Neteler, M., Bowman, M., Land, H. and Metz, M. (2012) GRASS GIS: A Multi-Purpose Open Source GIS. Environmental Modeling and Software, 31, 124-130. https://doi.org/10.1016/j.envsoft.2011.11.014

[10] Weier, J. and Herring, D. (2000) Measuring Vegetation (NDVI \& EVI). NASA Earth Observatory, Washington DC.

[11] Vrieling, A., Leeuw, J. and Said, M.Y. (2013) Length of Growing Period over Africa: Variability and Trends from 30 Years of NDVI Time Series. Remote Sensing, 5, 9821000. https://doi.org/10.3390/rs5020982

[12] Zhu, Z., Bi, L., Pan, Y., Ganguly, S., Anav, A., Xu, L., Samanta, A., Piao, S., Nemani, R.R. and Myneni, R.B. (2013) Global Data Sets of Vegetation Leaf Area Index (LAI) $3 \mathrm{~g}$ and Fraction of Photosynthetically Active Radiation (FPAR)3g Derived from Global Inventory Modeling and Mapping Studies (GIMMS) Normalized Difference Vegetation Index (NDVI3g) for the Period 1981 to 2011. Remote Sensing, 5, 927-948. https://doi.org/10.3390/rs5020927

[13] DeFries, R. and Townshend, J. (1994) NDVI-Derived Land Cover Classification at Global Scale. International Journal of Remote Sensing, 15, 3567-3586.

[14] DeFries, R., Hansen, M. and Townshend, J. (1995) Global Discrimination of Land Cover Types from Metrics Derived from AVHRR Pathfinder Data. Remote Sensing of Environment, 54, 209-222. https://doi.org/10.1016/0034-4257(95)00142-5

[15] Kobayashi, H. and Dye, D. (2005) Atmospheric Conditions for Monitoring the LongTerm Dynamics in the Amazon Using Normalized Difference Vegetation Index. Remote Sensing of Environment, 97, 519-525. 
https://doi.org/10.1016/j.rse.2005.06.007

[16] Michener W.K. and Houhoulis P.F. (1997) Detection of Vegetation Changes Associated with Extensive Flooding in a Forested Ecosystem. Photogrammetric Engineering and Remote Sensing, 63, 1363-1374.

[17] Lugo, A.E. (2000) Effects and Outcomes of a Caribbean Hurricane in Climate Change Scenario. Science to the Total Environment, 262, 243-251. https://doi.org/10.1016/S0048-9697(00)00526-X

[18] Rodgers, J.C., Cooke, W.H. and Murrah, A.W. (2009) The Impact of Hurricane Katrina on the Coastal Vegetation of the Weeks Bay Reserve, Alabama from NDVI Data. Estuaries and Coasts, 32, 496-507. https://doi.org/10.1007/s12237-009-9138-Z

[19] Wang, F. and D'Sa, E.J. (2010) Potential of MODIS EVI in Identifying Hurricane Disturbance to Coastal Vegetation in the Northern Gulf of Mexico. Remote Sensing, 2, 1-18. https://www.mdpi.com/journal/remotesensing https://doi.org/10.3390/rs2010001

[20] Parenti, M.S. (2015). Hurricane Effects on Mangrove Canopies Observed from MODIS and SPOT Imagery. SBCC Environmental Engineering and Science, Las Vegas, January 2015, Nevada 89148.

[21] Nicholson, S.E., Davenport, M.L. and Malo, A.R. (1990) A Comparison of the Vegetation Response to Rainfall in the Sahel and East Africa, Using Normalized Difference Vegetation Index from NOAA AVHRR. Climatic Change, 17, 209-241. https://doi.org/10.1007/BF00138369

[22] Nicholson, S.E. and Farrar, T.J. (1994) The Influence of Soil type on the Relationships between NDVI, Rainfall, and Soil Moisture in Semiarid Botswana. I. NDVI response to rainfall. Remote Sensing of Environment, 50, 107-120. https://doi.org/10.1016/0034-4257(94)90038-8

[23] Anyamba, A., Tucker, C.J. and Eastman, J.R. (2001) NDVI Anomaly Pattern over East Africa during the 1997/98 ENSO Warm Event. International Journal of Remote Sensing, 22, 1847-1859. https://doi.org/10.1080/01431160010029156

[24] Mutemi, J.N. (2003) Climate Anomalies over Eastern Africa Associated with Various ENSO Evolution Phases. Ph.D. Thesis, University of Nairobi, Nairobi.

[25] Mahongo, S.B., Francis, J. and Osima, S.E. (2012) Wind Patterns of Coastal Tanzania: Their Variability and Trends. Western Indian Ocean Journal of Marine Sciences, 10, 107-120.

[26] Sherman, R.E., Fahey, T.J. and Battles, J.J. (2000) Small-Scale Disturbance and Regeneration Dynamics in a Neotropical Mangrove Forest. Journal of Ecology, 88, 165 178. https://doi.org/10.1046/j.1365-2745.2000.00439.x

[27] Ramsey, E.W., Chappell, D.K., Jacobs, D.M., Sapkota, S.K. and Baldwin, D.G. (1998) Resource Management of Forested Wetlands: Hurricane Impact and Recovery Mapped by Combining Landsat TM and NOAA AVHRR Data. Photogrammetric Engineering \& Remote Sensing, 64, 733-738.

[28] Gao, X., Huete, A.R., Ni, W. and Miura, T. (2000) Optical-Biophysical Relationships of Vegetation Spectra without Background Contamination. Remote Sensing of Environment, 74, 609-620. https://doi.org/10.1016/S0034-4257(00)00150-4

[29] Running, S.W. and Nemani, R. (1998) Relating Seasonal Patterns of the AVHRR Vegetation Index to Simulated Photosynthesis and Transpiration of Forests in Different Climates. Remote Sensing of Environment, 24, 347-367.

https://doi.org/10.1016/0034-4257(88)90034-X

[30] Wylie, B.K., Johnson, D.A., Laca, E., Saliendra, N.Z., Gilmanov, T.G., Reed, B.C., 
Tieszen, L.L. and Worstell, B.B. (2003) Calibration of Remotely Sensed, Coarse Resolution NDVI to $\mathrm{CO}_{2}$ Fluxes in a Sagebrush-Steppe Ecosystem. Remote Sensing Environment, 85, 243-255. https://doi.org/10.1016/S0034-4257(03)00004-X

[31] Turpie, J.K. (2000) The Use and Value of Natural Resources of the Rufjiji Floodplain and Delta, Tanzania. Unpublished Report to IUCN (EARO), International Union for Conservation of Nature (IUCN), Gland, $108 \mathrm{p}$.

[32] Semesi, A.K. and Howell, K. (1992) The Mangrove of East African Region. United Nations Environment Programme, Nairobi.

[33] Punwong, P. (2013) Holocene Mangrove Dynamics and Sea Level Changes: Records from the Tanzanian Coast. Thesis Submitted in Fulfillment for the Degree of Doctor of Philosophy, University of York, York.

[34] Fisher, P.R., Dyer, K. and Semesi, A. (1994) Rufiji Delta Hydrodynamics Research Program, Final Report: Characteristic Circulation and Sedimentation in the Rufiji Delta, Tanzania. Frontier-Tanzania Technical Report No. 13, The Society for Environment Exploration, UK.

[35] Mavume, A.F., Rydberg, L., Mathieu, R. and Lutjeharms, J.R.E. (2009) Climatology and Landfall of Tropical Cyclones in the South West Indian Ocean. Western Indian Ocean Journal of Marine Sciences, 8, 15-36. https://doi.org/10.4314/wiojms.v8i1.56672

[36] Stéphanie, D. and Hamerlynck, O. (2007) The Rufiji River Flood: Plague or Blessing? International Journal of Biometeorol, 52, 33-42.

https://doi.org/10.1007/s00484-007-0105-8

[37] Shaghude, Y.W. (2004) Coastal Impacts of Water Abstraction and Impoundment in Africa: The Case of Rufiji River. Final Report Submitted to START, Published in OceanDocs: E-Repository of Ocean Publications, 75 p. http://iodeweb1.vliz.be/odin/bitstream /1834/187/1coastal.pdf

[38] Cederlof, U., Rydberg, L., Mgendi, M. and Mwaipopo, O. (1995) Tidal Exchange in a Warm Tropical Lagoon: Chwaka Bay, Zanzibar. Ambio, 24, 458-464.

[39] Shaghude, Y.W., Mahongo, S., Musuka, N.N. and Nyandwi, N. (2012) Physical and Geological Proceses in Chwaka Bay. In: de la Torre-Castro, M. and Lyimo, T.J., Eds., People Nature and Research in Chwaka Bay Zanzibar Tanzania, Western Indian Ocean Marine Science Association (WIOMSA), Znzibar Town, 41-55.

[40] Mohammed, S.M. and Johnstone, R.W. (1995) Spatial and Temporal Variations in Water Column Nutrients Concentration in a Tidally Dominated Mangrove Creeks; Chwaka Bay, Zanzibar. Ambio, 24, 482-486.

[41] Streusand, R. (2007) Impacts of Nature Traits on Jozani Forest, Zanzibar. Institute of Marine Sciences, Zanzibar, $34 \mathrm{p}$.

[42] Semesi, I.S. (2012) The Coastal Vegetation of Chwaka Bay. In: de la Torre-Castro, M. and Lyimo, T.J., Eds., People Nature and Research in Chwaka Bay Zanzibar Tanzania, Western Indian Ocean Marine Science Association (WIOMSA), Zanzibar Town, 57-63.

[43] Jury, M.R. and Parker, B.A. (1999) Synoptic Environment of Composite Tropical Cyclones in the South-West Indian Ocean. South African Journal of Marine Sciences, 21, 99-115. https://doi.org/10.2989/025776199784126105

[44] Vitart, F., Anderson, D. and Stockdal, T. (2003) Seasonal Forecasting of Tropical Cyclone Landfall over Mozambique. Journal of Climate, 16, 3932-3945. https://doi.org/10.1175/1520-0442(2003)016\%3C3932:SFOTCL\%3E2.0.CO;2

[45] Kai, K.H. (2018) Impacts of Southwestern Indian Ocean Tropical Cyclones and Storms 
on the Rainfall Pattern and Vegetation Productivity over Tanzania. Thesis, the Institute of Marine Sciences of the University of Dar Es Salaam, Dar Es Salaam.

[46] Kai, K.H., Kijazi, A.L. and Osima, S.E. (2020). An Assessment of the Seasonal Rainfall and Its Societal Implications in Zanzibar Islands during the Season of October to December, 2019. Atmospheric and Climate Sciences, 10, 509-529. https://doi.org/10.4236/acs.2020.104026

[47] Kai, K.H., Ngwali, M.K. and Faki, M.M. (2021) Assessment of the Impacts of Tropical Cyclone Fantala to Tanzania Coastal Line: Case Study of Zanzibar. Atmospheric and Climate Sciences, 11, 245-266. https://doi.org/10.4236/acs.2021.112015

[48] Mwakapuja, F., Liwa, M.F. and Kashaigili, J. (2013) Use of Indices for Extraction of Build Up Areas and Vegetation Features from Land sat TM Image: A Case of Dar es Salaam and Kisarawe Peri-Urban Areas, Tanzania. International Journal of Agriculture and Forestry, 3, 273-283.

[49] Vogelmann, J.E., Howard, S.M., Yang, L., Larson, C.R., Wylie, B.K. and Van driel, N. (2001) Completion of the 1990s National Land Cover Data Set for the Conterminous United States from Landsat Thematic Mapper Data and Ancillary Data Sources. American Society for Photogrammetry and Remote Sensing.

[50] Huffman, G.J., Adler, R.F., Bolvin, D.T. and Nelkin, E.J. (2010) The TRMM Multi-Satellite Precipitation Analysis (TMPA) (Chapter 1). In: Hossain, F. and Gebremichael M., Eds., Satellite Rainfall Applications for Surface Hydrology, Springer Verlag, Berlin, 3-22. https://doi.org/10.1007/978-90-481-2915-7 1

[51] Huffman, G.J., Adler, R.F., Bolvin, D.T. and Gu, G. (2009) Improving the Global Precipitation Record: GPCP Version 2.1. Geophysical Research Letters, 36, L17808. https://doi.org/10.1029/2009GL040000

[52] Heute, A., Didan, K., Miura, T., Rodriguez, E.P., Gao, X. and Ferreira, L.G. (2002) Overview of the Radiometric and Biophysical Performance of the MODIS Vegetation Indices. Remote Sensing of Environment, 83, 195-213. https://doi.org/10.1016/S0034-4257(02)00096-2

[53] Moritz, L. (2005) Geographic Resources Analysis Support System (GRASS) Tutorial. Published on 2005/04/26.

https://grass.osgeo.org/gdp/grass5tutor/grass50 tutorial en.pdf\%20\%20notes $\% 20 \%$ 20on\%20\%20http://grass.itc.it/ http://grass.itc.it/gdp/handbuch/index.html

[54] Yuan, F. and Bauer, M.E. (2007) Comparison of Impervious Surface Area and Normalized Difference Vegetation Index as Indicators of Surface Urban Heat Island Effects in Landsat Imagery. Remote Sensing of Environment, 106, 375-386. https://doi.org/10.1016/j.rse.2006.09.003

[55] Jonathan, D.W., Jennifer, L.I. and Camargo, S.J. (2013) Coastal Flooding by Tropical Cyclones and Sea-Level Rise. Nature, 504, 44-52.

https://doi.org/10.1038/nature12855

[56] Henderson-Sellers, A., Zhang, H., Berz, G., Emanuel, K., Gray, W., Landsea, C., Holland, G., Lighthill, J., Shieh, S.-L., Webster, P. and McGuffie, K. (1998) Tropical Cyclones and Global Climate Change, A Post-IPCC Assessment. Bulletin of the American Meteorological Society, 79, 19-38. https://doi.org/10.1175/1520-0477(1998)079<0019:TCAGCC >2.0.CO;2

[57] Song, J., Ding, X., Feng, G. and Zhang, F. (2006) Nutritional and Osmotic Roles of Nitrate in Euhalophyte and Xenophyte in Saline Conditions. New Phytologist, 171, 357-366. https://doi.org/10.1111/j.1469-8137.2006.01748.x

[58] Yang, W.C., Lin, K.H., Wu, C.W., Chang, Y.J. and Chang, Y.S. (2020) Effects of Water 
Logging with Different Water Resources on Plant Growth and Tolerance Capacity of Four Herbaceous Flowers in a Bioretention. Water, 12, Article No. 1619.

https://www.mdpi.com/journal/water

https://doi.org/10.3390/w12061619

[59] Mangora, M.M., Mtolera, M.S.P. and Bjork, M. (2014) Photosynthetic Responses to Submergence in Mangrove Seedlings. Marine and Freshwater Research, 65, 497-504. https://doi.org/10.1071/MF13167

[60] Di Martino, C., Sebastiano, D., Pizzuto, R., Loreto, F. and Fyggi, A. (2003) Free Amino Acids and Glycine Betaine in Leaf Osmoregulation of Spinach Responding to Increasing Salt Stress. New Phytologist, 158, 455-463.

https://doi.org/10.1046/j.1469-8137.2003.00770.x 